\title{
MEDAILON/MEDALLION
}

\section{GEORGE HEIN MASTER TEACHER}

\section{MARY ALEXANDER}

"I have always admired and respected George Hein as a scholar: he asks deep questions in pursuit of clarity of thought, studies original documents to find the essence of others' thinking (as he has done so beautifully with Dewey), and he writes with precision and clarity so readers can begin to grasp complex ideas."

Randi Korn, Founding Director, Randi Korn \&Associates

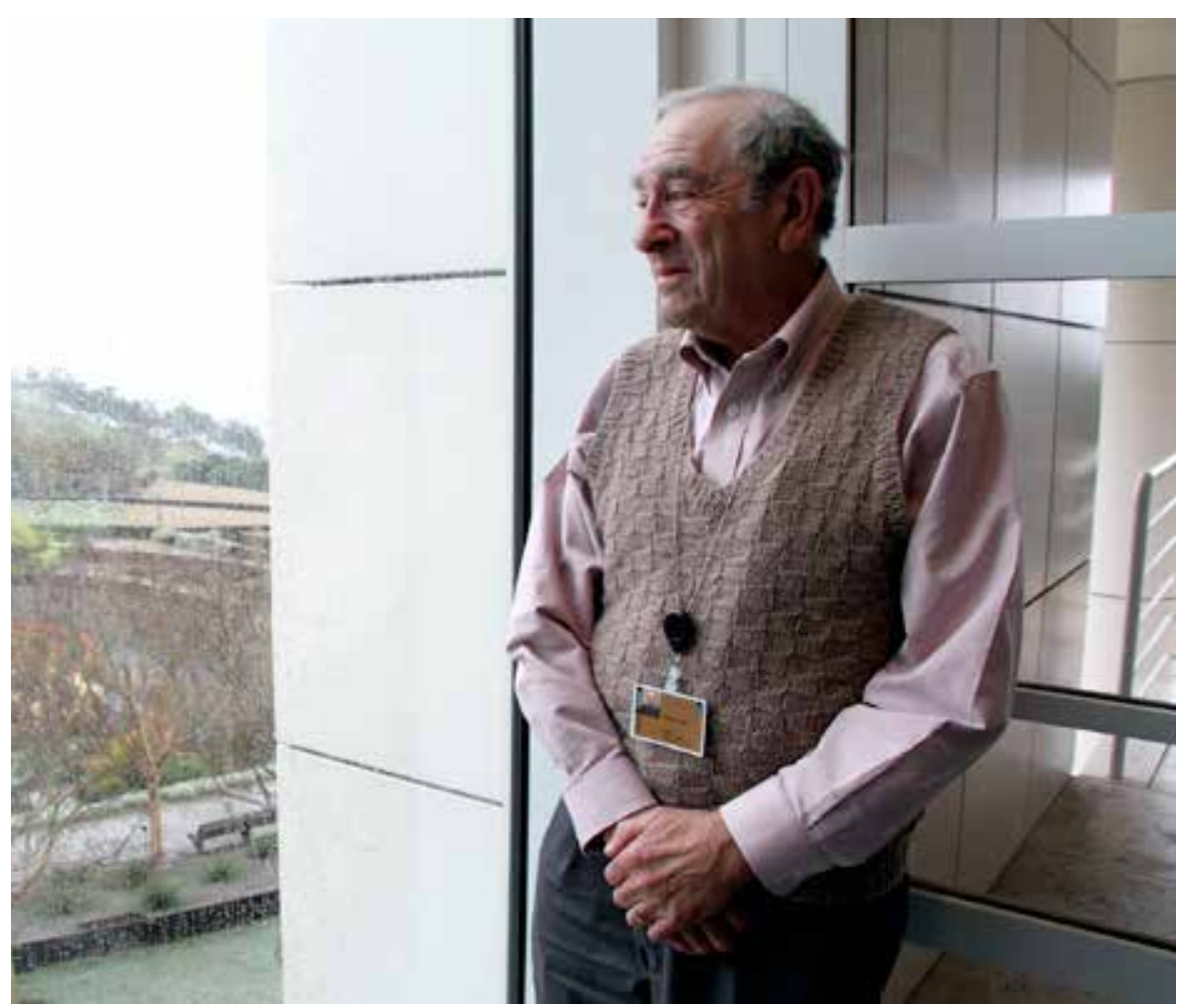

Fig. 1: George Hein, Getty Institute

Dr. George Hein was trained as a chemist, taught at the university level, worked as a curriculum developer for a national education project in the 1960s, entered the realm of museum evaluation and began to think and most importantly write about museums as educational institutions. In addition to his scholarship, George has been an able administrator leading the Lesley College (Cambridge, Massachusetts)
Independent Study Program for more than a decade.

George Hein is a natural teacher, both in the classroom and in informal settings from workshops to professional conference sessions. His formal presentations are informative and engaging to his audiences. His work with students one-on-one is masterful as guide, critic and, best of all, mentor. This skill also serves him well in the role of consultant, whether to individual museums or professional organizations. George's advice is always offered in a manner that benefits the project, the people involved and the parent organization.

I met George in 1982 when I was planning the Committee on Education and Cultural Action (CECA)-American Association of Museums (AAM) conference in Washington, DC. He was recommended as a speaker. Little did I know that he would become a close friend and later a co-author. From that experience with the CECA meeting, George went on to be its chair from 1992-1995. He has influenced CECA programs, highlighting professional practices in venues all around the world. In addition to leading CECA, George also joined the AAM-ICOM (International Council of Museums) board from 1998 to 2001 . He has been especially helpful bringing non-American museum professionals to the AAM annual meetings, encouraging a robust international exchange.

George's role as an outside evaluator for museums has been international and significant. Once again, his teaching talents contribute to his success with measuring program effectiveness. George founded Program Evaluation and Research Group (PERG) in 1976 with Lesley College colleague Brenda Engel initially to evaluate educational work of 25 museums and arts organizations in the Boston area. He has been active in museum education and evaluation ever since, specializing 
in qualitative in-depth evaluations of programs, as well as visitor research in museums. He has been most involved with assessing programs for the Exploratorium (San Francisco), Boston Children's Museum and the Museum of Science (Boston) and, more recently the Barnes Foundation (Philadelphia). George's work with museum evaluation has led to his close involvement with the National Science Foundation's (NSF) programs on public appreciation of science. George has served as an NSF grant reviewer as well as an advisor to the agency as it has assessed and modified its programs relating to informal learning. He has also been active in the Visitors Studies Association through its editorial committee, most recently serving as book review editor.

At Lesley College, George's work has been important to museums in two ways. His leadership in museum evaluation has been exemplary. His consulting group, Program Evaluation and Research Group (PERG) has assisted museums in better understanding their practices and sharing that knowledge across the profession. Through PERG, George helped to raise the quality of museum practice. But, what has impressed me most is his work with graduate students in Lesley's unique interdisciplinary program. George's students have been a mix of very interesting (and talented) young and, not so young, emerging museum professionals. Their variety is as impressive as their individual talents. Again, George's ability as teacher and mentor is extraordinary as he has guided these students into successful museum, or museum-related, careers.

Senior museum professionals too often complain about the lack of professional literature and promise to write about their experiences; George Hein actually has done just that, writing for the field based on his knowledge and experience. Learning in Museums published in 1998 is a valuable text for museum education professionals; in fact, for all professionals working in museums. In that same year, George and I wrote Museums: Places of Learning to mark the 30th anniversary of the AAM's Standing Professional Committee on Education. The latter volume is very popular in museum education training programs across the U.S. Of special import for both of these volumes is George's explication of the educational concept of "constructivism" and its value for museum education programs and exhibitions. I think it's fair to say that George has singlehandedly put constructivism on the agenda not only for U.S. museum educators, but around the world.

In recent years George began to focus his attention on U.S. philosopher and educator John Dewey and his influence on museum practices today. He became especially intrigued by Dewey's friendship with Alfred Barnes, who founded the Barnes' Foundation outside Philadelphia in the 1920s. Democracy and Museums: The Social Responsibility of Museums published in 2012 features Dewey and Barnes along with others. Once again, the teacher Hein has shared his inspiration with the field-at-large.

Over the years, George Hein has brought to the museum community his intellectual curiosity, the carefulness of a trained scientist, and his natural inclination to teach. The field has been enriched by each of those qualities. Here's what George is up to today, this report is from Laura Roberts (Roberts Consulting, Boston). "At the instigation of John Jacobsen
(White Oak Associates), George Hein, David Ellis (Museum of Science, Boston) and Laura Roberts (Roberts Consulting) meet for lunch every month at a Chinese restaurant in Cambridge. So we call our group Museum Stir Fry. We talk about issues and ideas. But most of all we overcome the isolation of consulting and/or retirement. This summer we launched a small demonstration project with nine mid sized museums to see if paying attention to performance metrics can have a positive impact. George is back at work teaching the participating museums and his colleagues."

\section{MARY ALEXANDER}

Museum Scholarship and Material Culture Program, University of Maryland, College Park, Maryland, U.S. 